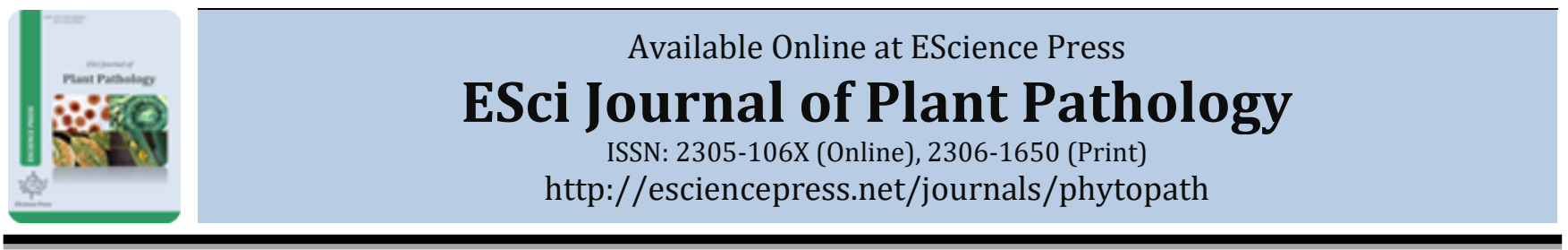

\title{
EVALUATION OF SOME POTENTIAL BOTANICALS TO CONTROL POTATO TUBER MOTH, (PHTHORIMAEA OPERCULELLA) UNDER STORAGE CONDITION AT BAKO, WESTERN ETHIOPIA
}

\author{
aschalew Sisay*, bAhmed Ibrahim \\ a Bako Agricultural Research Center, Bako, Ethiopia. \\ b Melkasa Agricultural Research Center, Ethiopia. \\ *Corresponding Author Email: aschsisay638@yahoo.com
}

\section{A B S T R A C T}

Lantana camara, Eucalyptus globulus, Tagetus minuta, Pyrethrum flowers and Azaddiractha indica, were evaluated against potato tuber moth damage with two checks (Diazinon 60\% EC and untreated check) at Bako Agricultural Research Center in 2007/2008 and 2008/2009 cropping seasons. A total of 21 huts (cottages) were constructed from locally available materials. Inside each cottage (hut), $1 \mathrm{~m}^{2}$ bed was constructed $65 \mathrm{~cm}$ above the ground. Six hundred fifty (650) potato tubers were stored on the bed of each hut in two layers one over the other. The treatments were arranged in a Randomized Complete Block Design (RCBD) with three replications. Plants powder and Diazinon 60\% EC were applied respectively, at the rate of $50 \mathrm{gm} /$ bed and 3.5ml / bed at two months' interval. The treatments that showed promising effects were further advanced on a large bed ( $2 \mathrm{~m}$ x $3 \mathrm{~m}$ ). Three thousand nine hundred (3900) potato tubers were stored on large beds and 150gm powders were used for each bed. Evaluations were made at the interval of 15 days for 7 consecutive months. Analysis of variance showed that number of potatoes infested and damaged by potato tuber moth was significantly $(\mathrm{P}<0.05)$ lower in the Lantana camara, Eucalyptus globulus and Pyrethrum flowers than the other treatments, which are similar to standard check. From the study it can be concluded that Lantana camara, E. globulus and Pyrethrum flowers can be used to protect seed potatoes from potato tuber moth damage in storage.

Keywords: Potato tuber moth, botanicals, chemical, potato.

\section{INTRODUCTION}

Potato is one of the major tuber crops that are grown in high lands of western Ethiopia, particularly around Bako area. It serves as food and income security to farmers, especially during seasonal food shortage and when grain is depleted from the store. It is a reliable food crop during erratic rainfall condition. The crop is indispensable in the areas because of geometrical increments of population and comparative advantage in terms of high yield per unit area and it has short vegetative growth period. The average yield of the world is 15t/ha whereas the average national yield for Ethiopia is about $5.3 \mathrm{t} / \mathrm{ha}$ (Salomone, 1985). However, the average for Western Oromia could be most likely lower than the national as well as world yield due to numerous farm constraints. Improved seed is one of the packages to be used to get high yield and they must be free from insect attack. But there are multifarious farming systems constraints and plagues that are imminent, inflicting great economic losses on potato tuber seeds in rustic storage system. Potato tuber moth is the bottleneck for getting high yields in the farming communities. Thus, the occurrence of potato tuber moth in the areas where potato tuber seeds are stored is the burning issue in farming community.

Good post-harvest handling is a determinant and crucial factor for uniform sprout growth, so that it will be free from insect attack. Unless protected in the storage, potato tuber moth (Phthorimaea operculella) is one of the noxious insect pests of stored potato tuber seeds. According to Anonymous (1980), storage losses due to storage pests varied from 30 to $70 \%$ in India and 
as high as $86 \%$ in Tunisia, Algeria and Turkey. Infestation of tubers in the field is estimated to be $50 \%$ in Peru. According to Adhanaom et al. (1985), potato tuber moth ( $P$. operculella) is the most damaging pest of potato in Ethiopia where the damage due to these pests could reach up to $91 \%$ in 90 days (Adahanom, 1985). However, no research had been conducted in western parts of Ethiopia to mitigate the problems except screening resistant genotypes for potato tuber moth. The widely adopted method to control potato tuber moth is by chemical application. Currently, the adverse effect associated with the use of chemicals in terms of sustainable agriculture and effect on the environment and non-target organisms is widely recognized. Therefore, it is high time to search for alternatives that are effective, sustainable, environmentally safe and economically feasible. The use of natural plant products with insecticide properties and is ecologically friendly has been found to be promising against potato tuber moth. According to Luis (2001) the use of extracts of wild coastal "tonuz" (Plucheachinyoyo) has shown to have great potential to control "Polill" (Phthorimaea operculella) in stored potato, a plague that inflicts great economic damage to Anden farmers. On the other hand, the use of Eucalyptus spp, Muna (Minthostachis spp) and Lantara camara has been reported by International Potato Center (CIP) as being capable of controlling pest attack in stored potato (Luis, 2001). Gabby Stoll (1996) also reported that it was possible to control Potato tuber moth by putting potato on the bed of Eucalyptus leaves. So the fight against harmful organisms is essential and it is necessary to develop appropriate technologies to manage pests. Environmentally friendly biological options do exist. These options based on natural crop production approaches that make use diversity in nature itself. One of natural crop protection approaches is the use of plants, which are having with insecticidal properties. Hence, the objective of the study was to evaluate the potentials of a diversity of natural botanicals as bio-insecticides for the control of potato tuber moth.

\section{MATERIALS AND METHODS}

Description of the study area: The experiment was conducted at Bako Agricultural Research Center, during $2007 / 2008$ and $2008 / 2009$. The center is located in east Wollega zone of Oromia National regional State, Western Ethiopia, at an altitude of $1650 \mathrm{msl}$. It lies between $9^{0} 6^{\prime}$ north latitude and $37^{\circ} 09^{\prime}$ east longitudes in the sub humid agro-ecology of the country at $260 \mathrm{~km}$ west of Addis Ababa. Average annual rain fall at this location is $1242 \mathrm{~mm}$. The rainy season covers the period of April to October and maximum rain is received in the month of July and August. Sixty percent of the soil is reddish brown Nitosols with a PH range of $5.0-5.31$. The minimum, maximum and average air temperatures are $13.2,27.9$ and $20.7^{\circ} \mathrm{C}$, respectively.

Trail Design, Treatment combination: Eucalyptus globulus, Tagetus minuta, Pyrethrum flowers and Azadiractha indica were evaluated against potato tuber moth with two checks (Diazinon 60\% EC and untreated check) for two years (2007/2008-2008/2009) at Bako Agricultural Research Center (Table 1). The experiment was arranged in Randomized Complete Block Design (RCBD) with three replications. A total of 21 huts (cottages) were constructed from locally available materials. The botanicals were obtained from the vicinity and an improved variety of potato (Menagesha) was multiplied at Bako Agricultural Research Center. Pyrethrum flower was obtained from Kulumsa Research Center.

Table 1: List of botanicals evaluated in 2007/2008 and 2008/2009 cropping seasons

\begin{tabular}{clll}
\hline No & Common name & Scientific name & Plant parts used \\
\hline $\mathbf{1}$ & Lantana camara & Lantana camara & Leaf powder \\
$\mathbf{2}$ & Eucalyptus Globulus. & Eucalyptus globulus. & Leaf powder \\
$\mathbf{3}$ & Tagetus minuta & Tagetus minuta & Leaf powder \\
$\mathbf{4}$ & Pyrethrum flowers & Chrysanthemum spp. & Flower powder \\
$\mathbf{5}$ & Neem & Azadrachta indica & Leaf powder \\
$\mathbf{6}$ & Diazinon $60 \%$ EC & - & Diazinon $60 \%$ EC \\
$\mathbf{7}$ & Control (Untreated check) & - & - \\
\hline
\end{tabular}


Treatment preparation and bed construction: The bed $\left(1 \mathrm{~m}^{2}\right.$ areas) was constructed inside each cottage, $65 \mathrm{~cm}$ above the ground with 650 potato tubers stored on each bed. The botanicals were dried under shade and ground into fine powder using mortar and pestle. Leaf and/ or flower powder of the botanicals and chemical were applied at the rate of $50 \mathrm{gm} / \mathrm{bed}$ and $3.5 \mathrm{ml}$ / bed, respectively, at two-month interval.

Data Collection and Analysis: Data were collected for the number of potatoes damaged by potato tuber moth and number of potatoes damaged by some factors other than potato tuber moth by counting the affected tubers at 15 days intervals for 7 consecutive months during each experimental period. Data were analyzed using SPSS and MSTATC software. Mean separations were done using SNMK range test.

RESULTS AND DISCUSSION Combined effects of different botanicals on percentages of potatoes infested and damaged by potato tuber moth, as well as potatoes damaged by diseases are presented in Table 2 . The percentages of potatoes infested and damaged by potato tuber moth were significantly lower in Lantana camara, Eucalyptus globules and Pyrethrum flowers than the other treatments. The percentage of potatoes damaged by diseases and other factors was significantly higher in all of the treatments and no significant differences were recorded among them (Table 2). Similar results were observed in the 2008/2009 experiment (Table 3). The percentages of potatoes infested by PTM were significantly $(\mathrm{P}<0.05)$ lower in Eucalyptus spp., Lantana camara and Diazinon, but significantly higher in the other treatments (Table 2). The percentages of potatoes damaged by PTM were significantly higher in Lantana camara, Tagetus minuta, Azadrachta indica and check, but significantly $(\mathrm{P}<0.05)$ lower in the other treatments (Table 2).

Table 2: Mean percentages of potatoes infested and damaged by potato tuber moth, and damaged by diseases and others factors at Bako $(2007 / 2008)$.

\begin{tabular}{lccc}
\hline Treatments & $\begin{array}{c}\text { \% age of potatoes } \\
\text { Infested by PTM }\end{array}$ & $\begin{array}{c}\text { \% age of potatoes } \\
\text { damaged by PTM }\end{array}$ & $\begin{array}{c}\text { \% of potatoes } \\
\text { damaged by diseases }\end{array}$ \\
\hline Lantana camara & $1.43 \pm 0.34 \mathrm{c}$ & $4.31 \pm 1.23 \mathrm{ab}$ & $0.56 \pm 0.18 \mathrm{a}$ \\
Eucalyptus spp. & $1.69 \pm 0.27 \mathrm{c}$ & $2.36 \pm 0.20 \mathrm{~b}$ & $0.87 \pm 0.13 \mathrm{a}$ \\
Tagetus minuta & $5.84 \pm 0.35 \mathrm{~b}$ & $6.61 \pm 1.07 \mathrm{a}$ & $0.77 \pm 0.09 \mathrm{a}$ \\
Pyrethrum flowers & $2.10 \pm 0.40 \mathrm{c}$ & $2.72 \pm 0.20 \mathrm{~b}$ & $1.13 \pm 0.05 \mathrm{a}$ \\
Azadiractha indica & $4.71 \pm 0.34 \mathrm{~b}$ & $5.59 \pm 0.34 \mathrm{a}$ & $0.82 \pm 0.10 \mathrm{a}$ \\
Diazinon 60\% EC & $1.18 \pm 0.13 \mathrm{c}$ & $1.89 \pm 0.67 \mathrm{~b}$ & $0.77 \pm 0.31 \mathrm{a}$ \\
Untreated Check & $6.61 \pm 0.87 \mathrm{a}$ & $5.89 \pm 0.48 \mathrm{a}$ & $0.72 \pm 0.13 \mathrm{a}$ \\
\hline CV\% & 19.59 & 29.67 & 18.29 \\
\hline Mean & 3.36 & 4.19 & 0.81 \\
\hline
\end{tabular}

Similar letters within the same column are not significantly different from each other at 5\% probability level (SNKRT).

Table 3: Mean percentages of potatoes infested and damaged by potato tuber moth, and damaged by diseases and other factors at Bako (2008/2009).

\begin{tabular}{lccc}
\hline Treatments & $\begin{array}{c}\text { \% age of potatoes } \\
\text { Infested by PTM }\end{array}$ & $\begin{array}{c}\text { \% age of potatoes } \\
\text { damaged by PTM }\end{array}$ & $\begin{array}{c}\text { \% of potatoes } \\
\text { damaged by diseases }\end{array}$ \\
\hline Lantana camara & $0.51 \pm 0.13 \mathrm{c}$ & $1.33 \pm 0.22 \mathrm{c}$ & $1.49 \pm 0.18 \mathrm{a}$ \\
Eucalyptus spp. & $0.56 \pm 0.13 \mathrm{c}$ & $1.38 \pm 0.18 \mathrm{c}$ & $1.54 \pm 1.54 \mathrm{a}$ \\
Tagetus minuta & $5.13 \pm 0.40 \mathrm{a}$ & $9.12 \pm 1.20 \mathrm{a}$ & $1.49 \pm 1.49 \mathrm{a}$ \\
Pyrethrum flowers & $1.59 \pm 0.18 \mathrm{c}$ & $3.23 \pm 1.12 \mathrm{bc}$ & $1.69 \pm 1.69 \mathrm{a}$ \\
Azadiractha indica & $3.49 \pm 0.41 \mathrm{~b}$ & $4.41 \pm 0.36 \mathrm{~b}$ & $1.13 \pm 1.13 \mathrm{a}$ \\
Diazinon 60\% EC & $0.72 \pm 0.22 \mathrm{c}$ & $1.13 \pm 0.34 \mathrm{c}$ & $1.64 \pm 1.64 \mathrm{a}$ \\
Check & $5.12 \pm 0.85 \mathrm{a}$ & $10.61 \pm 0.23 \mathrm{a}$ & $1.64 \pm 1.64 \mathrm{a}$ \\
Lantana camara & $0.51 \pm 0.13 \mathrm{c}$ & $1.33 \pm 0.22 \mathrm{c}$ & $1.49 \pm 0.18 \mathrm{a}$ \\
\hline CV\% & 29.11 & 25.82 & 21.36 \\
\hline Mean & 2.45 & 4.45 & 1.51 \\
\hline
\end{tabular}

Similar letters within the same column are not significantly different at 5\% probability level (SNK range test). 
Table 4: Combined effects of different botanicals on percentages of potatoes infested and damaged by potato tuber moth, and damaged by diseases and others factors at Bako (2007/2008 and 2008/2009).

\begin{tabular}{lccc}
\hline Treatments & $\begin{array}{c}\text { \% age of potatoes } \\
\text { Infested by PTM }\end{array}$ & $\begin{array}{c}\text { \% age of potatoes } \\
\text { damaged by PTM }\end{array}$ & $\begin{array}{c}\text { \% of potatoes } \\
\text { damaged by diseases }\end{array}$ \\
\hline Lantana camara & $0.97 \pm 0.26 \mathrm{c}$ & $2.82 \pm 0.87 \mathrm{c}$ & $1.03 \pm 0.24 \mathrm{a}$ \\
Eucalyptus spp. & $1.13 \pm 0.28 \mathrm{c}$ & $1.87 \pm 0.25 \mathrm{c}$ & $1.20 \pm 0.19 \mathrm{a}$ \\
Tagetus minuta & $5.48 \pm 0.29 \mathrm{a}$ & $7.87 \pm 0.91 \mathrm{a}$ & $1.13 \pm 0.19 \mathrm{a}$ \\
Pyrethrum flowers & $1.84 \pm 0.23 \mathrm{c}$ & $2.48 \pm 0.188 \mathrm{c}$ & $1.41 \pm 0.14 \mathrm{a}$ \\
Azadarachta indica & $4.10 \pm 0.36 \mathrm{~b}$ & $4.99 \pm 0.34 \mathrm{~b}$ & $0.97 \pm 0.12 \mathrm{a}$ \\
Diazinon 60\% EC & $0.95 \pm 0.16 \mathrm{c}$ & $1.51 \pm 0.37 \mathrm{c}$ & $1.20 \pm 0.24 \mathrm{a}$ \\
Untreated Check & $5.87 \pm 0.64 \mathrm{a}$ & $8.26 \pm 1.08 \mathrm{a}$ & $1.18 \pm 0.22 \mathrm{a}$ \\
\hline Lsd & 1.57 & 1.832 & 0.5167 \\
\hline Mean & 2.91 & 4.26 & 1.16 \\
\hline
\end{tabular}

Similar letters within the same column are not significantly different at 5\% probability level (SNK range test).

Besides, the percentages of potatoes infested or damaged by PTM was lower in Lantana camara, Eucalyptus globulus, Pyretherum flowers and Diazinon but higher in the other treatments (Table 3). The results of this study have shown that Eucalyptus spp, Pyrethrum flowers and Lantana camara showed potential effect against potato tuber moth (PTM) damage and comparable result was observed with Diazinon 60\% EC (Tables 2 and 3). These findings agreed with the research results reported by International Potato Center (IPC) that the use of some plant materials such as Lantana camara could control pest attack in stored potatoes (Luis, 2001). These botanicals might possess antifeedent, repellent, insecticidal properties or a combination of them in reducing the damage level caused by insect pests. According to the result of the work of Gabby Stoll, (1996) and the International Potato Center, it was possible to control PTM by storing potatoes on the bed of Eucalyptus leaves (Luis, 2001). On the other hand, some plants and weeds like Muna (Minthosstachys spp), Eucalyptus (Eucalyptus globulus), Chilca (Baccharis spp), Curry plants, Indian pivets, Lantana camara, Mentha arvensis and Artemesi vulgaris, Lycopersicon hirsutum etc were effective in controlling PTM (Kennedy, 1984; Pradhan, 1998).

\section{SUMMARY AND CONCLUSION}

The experiment was conducted at Bako Agricultural Research Center, west Shoa, Ethiopia with the objective of evaluating the efficacy of botanicals against potato tuber moth. In summary, the results obtained from our experiments agree with similar works somewhere else. Eucalyptus spp, Pyrethrum flowers and Lantana camara can effectively protect the seed potato tubers from potato tuber moth. To validate the results and optimize the usable, package formulation, rate and frequencies of application have to be determined. However, for the time being, the application of Eucalyptus spp, Pyretherum flowers powder and Lantana camara leaf powder at the rate of $50 \mathrm{gm} / 650$ numbers of potatoes at two months intervals can be used as a component of IPM by local farmers to tackle the problem of potato tuber moth (PTM).

\section{ACKNOWLEDGEMENT}

We are very grateful to crop protection division field assistance and field supervisor for their immeasurable and wholehearted efforts they made in managing the field. Our special thanks go to Mr. Teshome Bogale and Mr Tadesse Birhanu for their enthusiastic efforts they made in collecting the data. We wish to extend our sincere thanks to Bako research center staff for kind cooperation.

\section{REFERENCES}

Negasi, A., Tsedeke abate \& E. Getu, 1985. Research on insect pest of root and tuber crops in Ethiopia, Tsedeke A (ed) pro. First Ethiopian crop protection symposium, Addis Ababa, Ethiopia.

Anonymous. 1980. Annual report of international potato center (CIP) Lima, Peru.

Oserio, L. G., 2001. Plants protecting other plants. Alternative methods to pest resistant. Magazine on low external inputs and sustainable agriculture. Action network on pesticides and thier alternative in latine America. V-17, n-4, pp. 23-24. 
Palecios, M. \& F. Cisnerose. 1997. Interntional potatoes center. Integrated pest management for the potato tuber moth in pilot units in the Anden Region and Dominica Republic Lima Peru.

Yilma, S. 1985. Review of potato research in Ethiopia. First Ethiopian Horticultural work shop. p.294. Institute of Agricultural Research (IAR). Addis Ababa Ethiopia.

Stool, G. 1996. Natural crop protection based on local farm resource in the tropics. An information center with in the network for sustainable agriculture in the third wold Countries, Germany, pp. 118-124.

Tindal, H.D. 1983. Potato preparation for market and storage. Vegetable in tropics, Hong kong, pp. 37576.

Kennedy, G.M. 1984. 2-Tridecanone, tomatoes and heliothis zea potential incompatibility of plants and antibiotics with insecticidal control. Entomol. Exp. Appl. 35,305.

Publisher's note: EScience Press remains neutral with regard to jurisdictional claims in published maps and institutional affiliations.

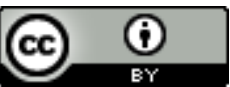

Open Access This article is licensed under a Creative Commons Attribution 4.0 International License. To view a copy of this license, visit http://creativecommons.org/licenses/by/4.0/.

(C) The Author(s) 2012 